\title{
Size-specific movement of green sea urchins Strongylocentrotus droebachiensis on urchin barrens in eastern Canada
}

\author{
Clément Dumont ${ }^{1, *}$, John H. Himmelman' ${ }^{1}$, Michael P. Russell ${ }^{2}$ \\ ${ }^{1}$ Département de Biologie and Québec-Océan, Université Laval, Québec GIK7P4, Canada \\ ${ }^{2}$ Biology Department, Villanova University, Villanova, Pennsylvania 19085-1699, USA
}

\begin{abstract}
Movement is likely a major factor contributing to the marked size partitioning of populations in relation to depth and habitat, as observed for many coastal invertebrates. Here, 2 approaches were used to examine the relationship of movement to size for the green sea urchin Strongylocentrotus droebachiensis on persistent urchin barrens in the northern Gulf of St. Lawrence, eastern Canada. The first approach involved quantifying the dispersal of tagged urchins from release points. Experiments were started by tagging all urchins in $1.0 \mathrm{~m}^{2}$ plots with a fluorescent stain, then quantifying their abundance 9 or $40 \mathrm{~d}$ later in the release plots and at different distances from the release plots. The rate of dispersal of urchins from the plots varied greatly with size. In the initial plots, we recaptured $69 \%$ of $<10 \mathrm{~mm}$ diameter urchins, compared to $2 \%$ for $>15 \mathrm{~mm}$ diameter urchins, after $9 \mathrm{~d}$, and 25 and $0 \%$, respectively, after $40 \mathrm{~d}$. In 5 of 6 trials executed, movement was directional, albeit in different directions in the different trials. The second approach evaluated urchin movement relative to size by quantifying the numbers of different-sized urchins moving into $1.0 \mathrm{~m}^{2}$ circular plots, from which the natural population of urchins had been removed $48 \mathrm{~h}$ earlier. Trials were made either with or without algae in the center of the plots. After $48 \mathrm{~h}$ most urchins which had moved into the plots were large (>15 $\mathrm{mm}$ diameter). The movement of urchins was size-dependent, as the presence of algal food affected the rates of movement of large urchins into the plots, but had no detectable effect on small ( $<15 \mathrm{~mm}$ diameter) urchins. Both approaches demonstrated that urchins measuring $<15 \mathrm{~mm}$ diameter (juveniles) have a relatively sedentary and cryptic lifestyle. Those $>15 \mathrm{~mm}$ diameter showed increased movement, probably related to the search for food. This ontogenetic change in movement likely affects growth rates and contributes to size partitioning of urchin populations in different subtidal habitats.
\end{abstract}

KEY WORDS: Strongylocentrotus droebachiensis - Dispersal - Movement - Urchin barrens . Ontogenetic shift

\section{INTRODUCTION}

The distribution of marine benthic invertebrates may be influenced by a variety of pre- and post-settlement processes including larval supply, settlement success, survival, competition, predation, and the differential movement of juveniles and adults. Post-settlement movement may allow juveniles and adults to avoid predation or competition and to locate food sources and favourable habitats (Meadows et al. 1972), and it has been shown that movement patterns are a major factor determining the distribution and size structure of local populations (Palmer et al. 1996).

In many temperate regions, sea urchins control the abundance and structure of macroalgae (Lawrence 1975, Dayton 1985) and influence the species diversity of benthic communities (Paine \& Vadas 1969). When in high densities, the green sea urchin Strongylocentrotus 
droebachiensis may form grazing fronts that can transform highly productive kelp beds into 'barrens' dominated by encrusting coralline algae (Bernstein et al. 1983, Scheibling et al. 1999). Grazing fronts can advance through kelp beds at a rate up to $4 \mathrm{~m} \mathrm{mo}^{-1}$ (see Scheibling \& Hatcher 2001 for review).

The size distributions of urchins vary greatly with habitat, juveniles being extremely abundant on barrens and in low densities in kelp beds (Scheibling \& Hatcher 2001). High recruitment probably accounts for the high densities on barrens, and predators may contribute to their low numbers in kelp beds (McNaught 1999, Balch \& Scheibling 2000). Juveniles on barrens avoid predators by hiding in crevices and under rocks, but this behaviour appears to shift with increasing size to active foraging on open surfaces (Keats et al. 1985, Himmelman 1986, Scheibling \& Hamm 1991). Several studies suggest that large urchins move from barrens to shallower macroalgal beds (Propp 1977, Meidel \& Scheibling 1998, Scheibling et al. 1999, Vadas et al. 2002). According to Garnick (1978), adult Strongylocentrotus droebachiensis often form aggregations and can cover up to $3 \mathrm{~m} \mathrm{~d}^{-1}$ when moving between aggregations.

Rates of movement can vary markedly with size. Ontogenetic changes in the movement have been documented in crabs (Hines et al. 1995) and lobsters (Wahle \& Steneck 1992). Although echinoids are important invertebrates in shallow waters, studies of their movement have been limited to large individuals (see Vadas 1990 for review, Agatsuma et al. 2000, Konar 2000, Duggan \& Miller 2001, Freeman 2003). Several authors have suggested an ontogenetic shift in movement of green sea urchins (e.g. Himmelman 1986, Scheibling et al. 1999). However, up until now, inadequate methodologies for tracking juveniles have prevented testing of this hypothesis.

Most of the tagging methods used for urchins are intrusive, probably affect their behaviour, and can only be applied to large individuals (Hagen 1996, Duggan 2001). Norkko et al. (2001) recently succeeded with a new technique, tagging with a fluorescent stain, to document the natural dispersal of juvenile bivalves over a short period. Although numerous researchers have used fluorescent marking of calcareous structures, such as the test and jaws (demi-pyramids of the Aristotle lantern), to quantify growth in urchins (Ebert 2001), fluorescent tagging has not been used as a tool for following the movement of urchins.

In the present study, we examined the movement of Strongylocentrotus droebachiensis in a persistent urchin barrens community in the northern Gulf of St. Lawrence, eastern Canada. Based on previous observations of the cryptic behaviour of small individuals, we hypothesized that the movement of urchins increases markedly with size. Specifically, we compared movement rates of different size classes of urchins by observing outward and inward movement at specific sites. Our outward movement trials used the fluorescent tagging method to track the dispersal of urchins from defined release sites and our inward movement trials quantified the movement urchins of different sizes into sites where the natural population of urchins had been removed. Because our outward movement study is the first to use fluorescent tagging to quantify movement in urchins, we further evaluated tagging success for different sized urchins.

\section{MATERIALS AND METHODS}

Our study area was located at Cap du Corbeau, Ile du Havre, in the Mingan Islands in the northern Gulf of St. Lawrence, eastern Canada $\left(50^{\circ} 13.6^{\prime \prime} \mathrm{N}\right.$, $63^{\circ} 41.12^{\prime \prime} \mathrm{W}$ ). This area is semi-protected with low velocity east/west tidal flow. Kelp (mainly Alaria esculenta) forms a narrow fringe on bedrock and boulders in shallow water (down to about $2 \mathrm{~m}$ depth), and seaward there are extensive urchin barrens. The experiments were conducted on a plateau of pebbles overlying mud and sand at 8 to $10 \mathrm{~m}$ depth. There were occasional patches of the brown algae Desmarestia viridis and Agarum cribrosum in this area, but none within $10 \mathrm{~m}$ of the experimental plots. We chose this area of the barrens because of the uniformity of the substratum and the greater size range of urchins than in shallower water (size-distributions at Cap du Corbeau are previously reported by Himmelman \& Nédélec 1990). Water temperature varied from 2 to $9^{\circ} \mathrm{C}$ during the study.

Emigration experiment. We studied the outward movement of different sizes of urchins by fluorescenttagging all individuals in six $1 \mathrm{~m}^{2}$ circular plots, and later sampling the same plots, as well as areas around the plots, to record movement. The plots were separated by at least $15 \mathrm{~m}$. In late June 2001, all urchins from each of the plots were collected and brought to the laboratory for size measurements (test diameter) and calcein tagging (see below). After a $24 \mathrm{~h}$ delay, the urchins were returned to the plots where they had been collected. To minimise movement caused by the experimental manipulation, the urchins were first kept in a cage for $24 \mathrm{~h}$ in each plot and then released. Just prior to releasing the urchins, any urchins that had moved into the circular plots were removed, so that the initial densities in the plots were identical to when the urchins were first collected. Thus, the trials started with the same urchins that were first collected in each plot (101 to 164 individuals per plot).

Of the plots, 3 were sampled $9 \mathrm{~d}$ later when all urchins were collected from each plot, as well as from 
twelve $25 \times 25 \mathrm{~cm}$ quadrats positioned in a ring between 25 and $50 \mathrm{~cm}$ from the plots (Fig. 1a). Urchins in the 3 remaining plots were sampled after $40 \mathrm{~d}$. Again, we collected all urchins in the release plots and in the 12 quadrats between 25 and $50 \mathrm{~cm}$ from the plots. We also collected the urchins from 12 quadrats positioned in an outer ring 75 to $100 \mathrm{~cm}$ from the plots (Fig. 1a). The proportions of recaptured urchins in the rings were adjusted relative to the area sampled (the inner 12 quadrats represented $51 \%$ of the $1.47 \mathrm{~m}^{2}$ area of the ring at 25 to $50 \mathrm{~cm}$ from the release plots, and the outer 12 quadrats represented $33 \%$ of the $2.25 \mathrm{~m}^{2}$ area of the ring at 75 to $100 \mathrm{~cm}$ from the release plots). Also, to evaluate directional movement of the urchins, the quadrats at 25 to 50 and 75 to $100 \mathrm{~cm}$ from the central plots were separated into north, south, east, and west.

All urchins collected from the original plots and peripheral quadrats were returned to the laboratory for processing. For each urchin, we measured test diameter and dissected out the Aristotle's lantern. The Aristotle's lanterns were cleaned in a $5 \%$ sodium hyperchlorite solution to remove soft tissue, washed in fresh water, and air dried. We later examined the jaws (demi-pyramids) under ultraviolet light to determine if the fluorescent tag was present (Kobayashi \& Taki 1969, Ebert 1988).

Fluorescent tagging was accomplished by placing the urchins for $24 \mathrm{~h}$ in a calcein bath $(0.625 \mathrm{~g}$ calcein and $0.5 \mathrm{~g}$ sodium bicarbonate in 301 of seawater; Russell \& Meredith 2000). As skeletal growth is required to incorporate the calcein into edges of calcareous structures (e.g. test plates and jaws), the urchins were provided with their preferred alga, Alaria esculenta, to stimulate growth. We also ran parallel trials to quantify tagging success. Three groups of small $(<20 \mathrm{~mm}$ diameter) and 3 of large ( $>20 \mathrm{~mm}$ diameter) urchins $(\mathrm{n}=$ 21 per group) were collected near the experimental plots at the same time and tagged in the same way. The urchins in the tagging trials were maintained with food in flowing water in the laboratory for $4 \mathrm{~d}$ before determining the proportion of individuals with a fluorescent mark on the jaws.

We compared recapture rates of the different size classes in the plots using a 2-way ANOVA with Time (2 levels: 9 and $40 \mathrm{~d}$ ) and Size (3 levels: <10, 10 to 15 and $>15 \mathrm{~mm}$ urchins) as factors. Student-NewmanKeuls tests (SNK) were used for a posteriori comparisons (Underwood 1997). We applied $\chi^{2}$-tests to the proportions of recaptured urchins in 4 different directions from the release plots (sampling in the rings around the plots) to evaluate whether dispersal was random or directional (Zar 1999).

To assess the degree to which the manipulations affected urchin densities in the experimental plots we

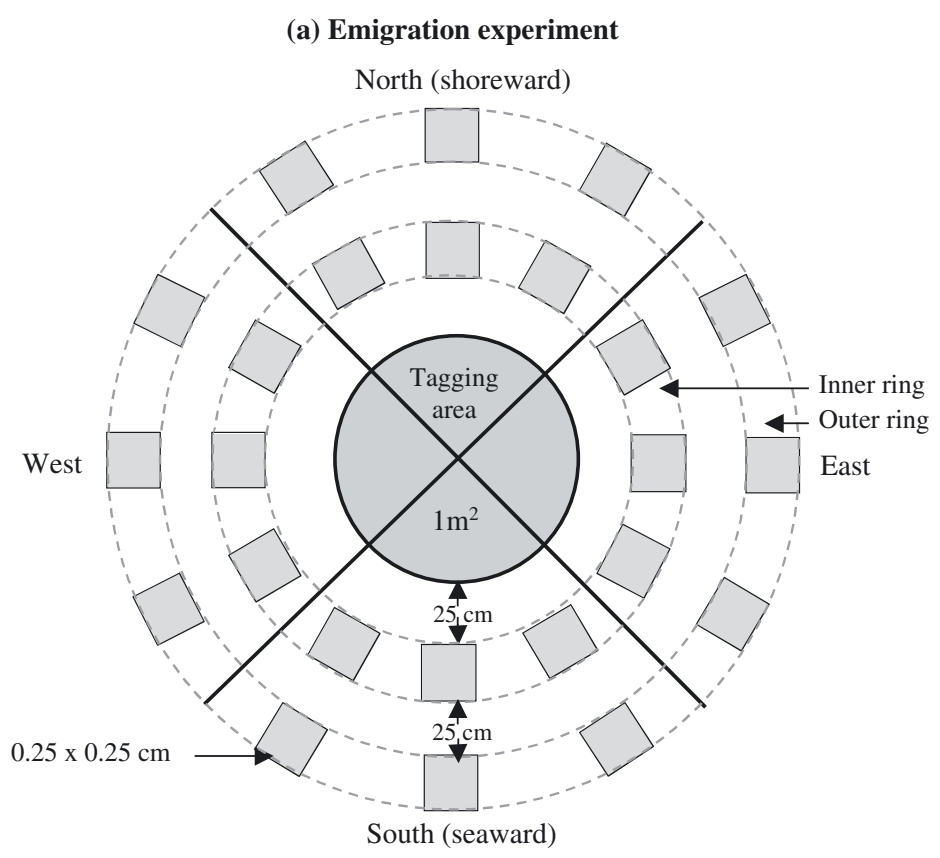

(b) Immigration experiment

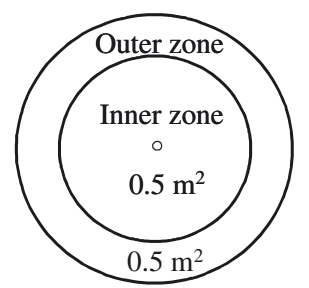

Fig. 1. (a) Experimental design and sampling strategy of the emigration experiment. Inner rings were sampled in both the 9 and $40 \mathrm{~d}$ experiments, and the outer rings were sampled in the $40 \mathrm{~d}$ only. Total area was $1.47 \mathrm{~m}^{2}$ for the inner ring and $2.25 \mathrm{~m}^{2}$ for the outer ring. Total area of the 12 quadrats $\left(0.75 \mathrm{~m}^{2}\right)$ represented $51 \%$ of the inner ring and $33 \%$ of the outer ring. (b) Experimental design and sampling strategy of the immigration experiment. After urchins were removed from each of the $1 \mathrm{~m}^{2}$ plots, 3 of the plots had a food source placed in the middle and 3 did not. After $48 \mathrm{~h}$ all urchins that had immigrated into the plots were collected from the 2 concentric zones (each $0.5 \mathrm{~m}^{2}$ )

used paired $t$-tests (Zar 1999) to compare urchin densities in the release plots at the start and end of the experiments, and densities in release plots with those in concentric rings around the release plots.

Immigration experiment. At the same site, we also quantified the movement of different sizes of urchins $(<10,10$ to $15,>15 \mathrm{~mm}$ diameter $)$ into six $1 \mathrm{~m}^{2}$ circular plots where the natural population of urchins had been removed. The trials were conducted between 25 June and 3 July 2001, and each trial began with the removal of all urchins from a $1 \mathrm{~m}^{2}$ plot identified with a numbered bolt in the center. We then resam- 
Table 1. Strongylocentrotus droebachiensis. Number of tagged and recaptured sea urchins 9 and $40 \mathrm{~d}$ after their release from the experimental plots $\left(1 \mathrm{~m}^{2}\right)$. To estimate the total tagged urchins present, the proportions recaptured for the inner rings $(25$ to $50 \mathrm{~cm})$ and outer rings $(75$ to $100 \mathrm{~cm}$ ) were adjusted to account for the areas (51 and $33 \%$, respectively; see Fig. 1) sampled from the rings

\begin{tabular}{|lrrr|}
\hline $\begin{array}{l}\text { Size } \\
(\mathrm{mm})\end{array}$ & $\begin{array}{c}\text { No. } \\
\text { tagged }\end{array}$ & $\begin{array}{c}\text { No. } \\
\text { recaptured }\end{array}$ & $\begin{array}{c}\text { Estimated recapture rate } \\
\text { of tagged urchins (\%) }\end{array}$ \\
\hline 9 d experiment & & \\
$<10$ & 127 & 99 & 87.8 \\
$10-15$ & 182 & 91 & 50.9 \\
$>15$ & 102 & 5 & 7.8 \\
$\mathbf{4 0}$ d experiment & & \\
$<10$ & 105 & 40 & 45.4 \\
$10-15$ & 217 & 55 & 41.8 \\
$>15$ & 77 & 0 & 0.0 \\
\hline
\end{tabular}

pled each plot $48 \mathrm{~h}$ later to collect urchins that had moved into the plot. In the sampling after $48 \mathrm{~h}$, to take in consideration the proximity of urchins at the edge of the plot, each circular area was divided into

$9 \mathrm{~d}$ experiment

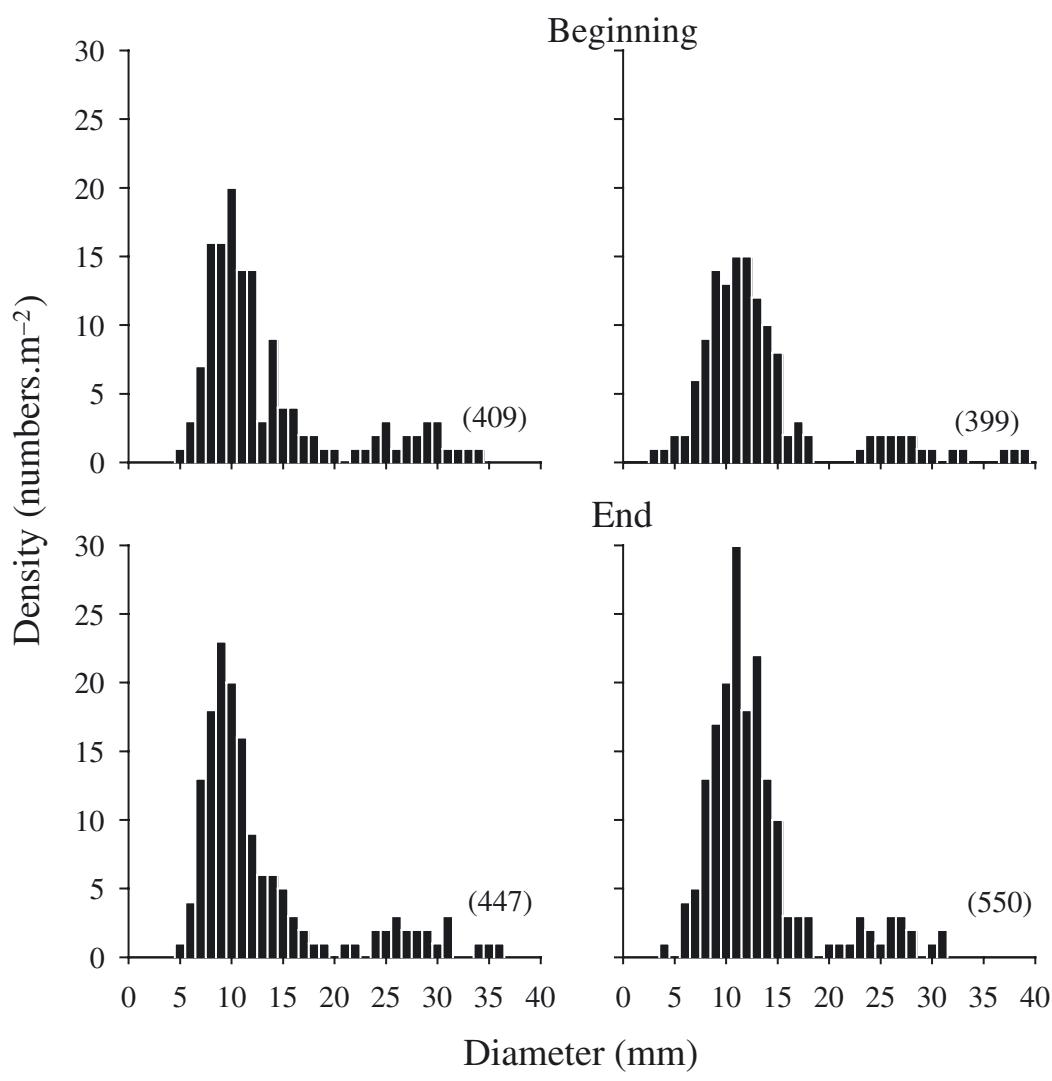

Fig. 2. Strongylocentrotus droebachiensis. Size distributions of sea urchins sampled in the experimental $1 \mathrm{~m}^{2}$ circular plots. Each histogram represents the combined total of 3 replicate plots (sample size in parentheses) sampled at the start (upper) and end (lower) of the $9 \mathrm{~d}$ and $40 \mathrm{~d}$ experiments inner and outer zones ( 0 to 40 and 40 to $56 \mathrm{~cm}$ from the center), each with an area of $0.5 \mathrm{~m}^{2}$ (Fig. 1b). To evaluate the effect of the presence of macroalgal food on the immigration of different-sized urchins, we attached a $5 \times 15 \mathrm{~cm}$ piece of a preferred food, the alga Alaria esculenta, to the bolt in the center of 3 of the 6 plots just after the removal of urchins. Given the difference in distance of urchins in the 2 zones from the natural population, the data for the inner and outer zones were analyzed separately using 2-way ANOVAs, with the factors Food (present or absent) and Size of urchins $(<10,10$ to 15 , $>15 \mathrm{~mm}$ diameter), and followed with SNK tests (Underwood 1997). When the assumptions were not met (normality and homoscedasticity of data), ANOVAs were applied to both the raw and the ranktransformed data. We present the results of the former when they were the same for the 2 analyses (according to Conover 1980).

\section{RESULTS}

\section{Emigration experiment}

A total of 1973 urchins were dissected to recover 290 tagged urchins (Table 1). The tagging success trials showed that $96.8 \%$ (SE $=3.18)$ of small urchins $(<20 \mathrm{~mm}$ diameter $)$ and $71.4 \%$ (SE = 2.75 ) of large ( $>20 \mathrm{~mm}$ diameter) urchins were marked by calcein. These values represent minimal tagging success, as the marker was still possibly present in the urchins after $4 \mathrm{~d}$ and could have been incorporated into skeletal structures over a longer period. Here we present the unadjusted data, because adjusting recapture rates for tagging success did not change the general conclusions.

The sampling at the start and end of the emigration trials (Fig. 2) showed that the experimental manipulations had no detectable effect on the density of urchins in either the $9 \mathrm{~d}$ trials (paired $t$-tests for all sizes pooled, $t_{2}=1.23, \mathrm{p}=$ $0.34, \mathrm{n}=3)$ or $40 \mathrm{~d}$ trials $\left(t_{2}=-3.28, \mathrm{p}=\right.$ $0.08, \mathrm{n}=3$ ). Also, densities within the circular release plots were similar to those in the concentric rings around the release areas for both the $9 \mathrm{~d}$ trials (paired $t$-test for all sizes pooled, $t_{2}=$ $1.23, \mathrm{p}=0.34$ ) and $40 \mathrm{~d}$ trials (inner and outer rings pooled, $t_{2}=0.53, \mathrm{p}=0.65$ ). 
The spatial and temporal data on recapture rates supported our prediction that the rate of the dispersal of urchins increases with size (Fig. 3). The proportion of tagged urchins remaining in the $1 \mathrm{~m}^{2}$ circular plots decreased markedly with urchin size (Table 2). After $9 \mathrm{~d}, 69.3 \%$ of small juveniles $(<10 \mathrm{~mm}$ diameter $)$ were still in the release plots, compared to $37.7 \%$ for large juveniles (10 to $15 \mathrm{~mm}$ diameter) and $1.7 \%$ for adults (>15 mm diameter) (Fig. 3). After $40 \mathrm{~d}$, the percentage of small and large juveniles in the release plots fell to 24.7 and $18.6 \%$, respectively, and no adults were present.

The dispersal of tagged urchins from the circular release plots was further shown by the sampling in the concentric zones around the plots (Fig. 4). The percentage of small and large juveniles in the inner ring (at 25 to $50 \mathrm{~cm}$ ) was 12.3 and $11.3 \%$ after $9 \mathrm{~d}$ and fell to 7.9 and $6.3 \%$ after $40 \mathrm{~d}$. The outward movement of large juveniles from the release plots appeared to be greater than for small juveniles, as only large juveniles were recaptured in the outer ring (at 75 to $100 \mathrm{~cm}$ ) after $40 \mathrm{~d}$.

The rate of disappearance of adults $(>15 \mathrm{~mm}$ diameter) during the $9 \mathrm{~d}$ and $40 \mathrm{~d}$ trials was clearly higher than for small and large juveniles (Fig. 4). Only 5 tagged adults $(3.9 \%)$ were captured in the trials after

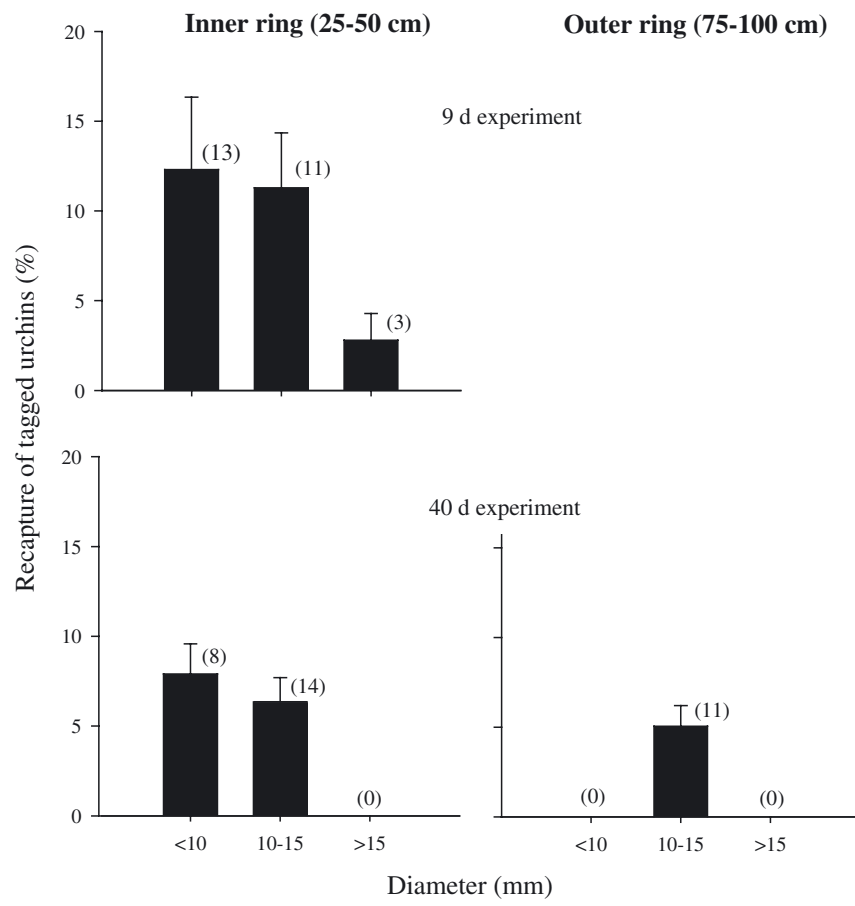

Fig. 4. Strongylocentrotus droebachiensis. Recaptured proportion of tagged sea urchins of 3 size classes $(<10,10$ to 15 and $>15 \mathrm{~mm}$ ) around the release plots after 9 and $40 \mathrm{~d}$. Numbers in parentheses indicate the number of individuals

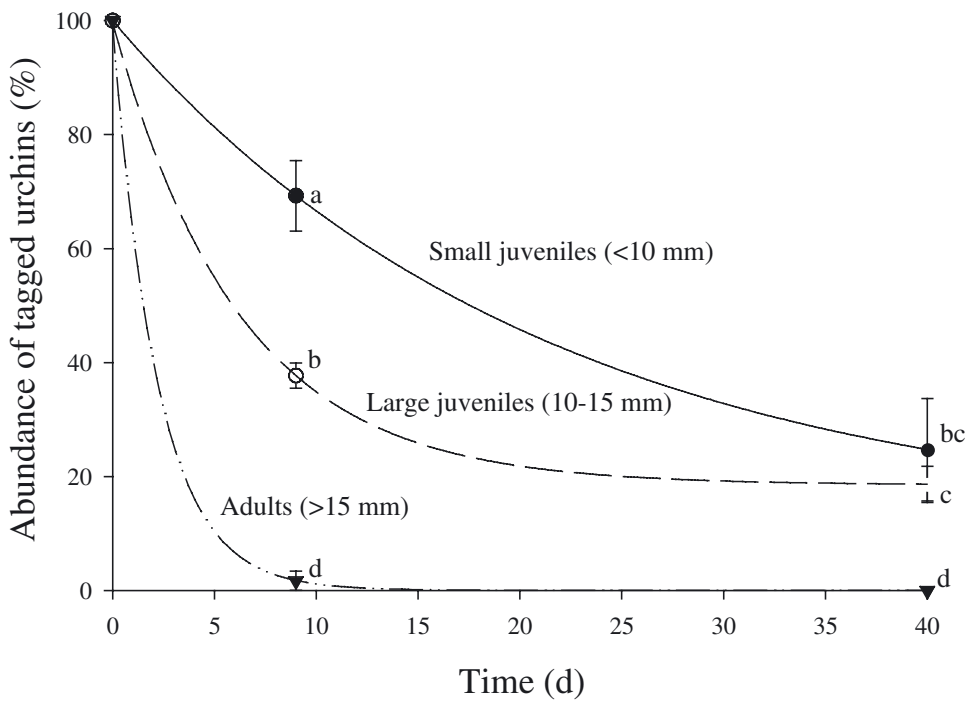

Fig. 3. Strongylocentrotus droebachiensis. Abundance decay of 3 size classes of urchins $(<10$ to 15 and $>15 \mathrm{~mm}$ ) as shown by the mean percent tagged individuals over time. Points sharing the same letter are not significantly different (SNK test, $\mathrm{p}<0.05$ ). Vertical bar are standard errors. Lines identify the 3 size groups

$9 \mathrm{~d}$ (2 measuring 16 and $25 \mathrm{~mm}$ in the release plots and 3 measuring 24,26 and $26 \mathrm{~mm}$ in the quadrats in the ring at 25 to $50 \mathrm{~cm}$ from the release plots) and none after $40 \mathrm{~d}$.

A directional movement was detected in the dispersal of urchins $\left(\chi^{2}\right.$-tests comparing our data to the expected random movement) in 5 of the 6 experimental plots (Fig. 5). However, orientation was not constant among the plots, or between the 2 sampling periods (after 9 and $40 \mathrm{~d}$ ), even though the trials were executed along the same shoreline (at Cap du Corbeau) which was exposed to the same general east-west tidal flow.

\section{Immigration experiment}

Sea urchin size and presence of food strongly affected the rates of inward movement into the $1 \mathrm{~m}^{2}$ plots previously cleared of urchins (Table 3, Fig. 6).

Table 2. Strongylocentrotus droebachiensis. Results of 2-way (Time, Size) ANOVA applied to the percentage of sea urchins recaptured in experimental plots during the emigration experiment (see Fig. 3)

\begin{tabular}{|lrrrr|}
\hline Source of variation & df & \multicolumn{1}{c}{ MS } & \multicolumn{1}{c|}{$F$} & \multicolumn{1}{c|}{ p } \\
\hline Time & 1 & 2134.2 & 31.3 & $<0.001$ \\
Size & 2 & 3226.7 & 47.3 & $<0.001$ \\
Time $\times$ Size & 2 & 696.1 & 10.2 & 0.003 \\
Residual & 12 & 68.2 & & \\
\hline
\end{tabular}




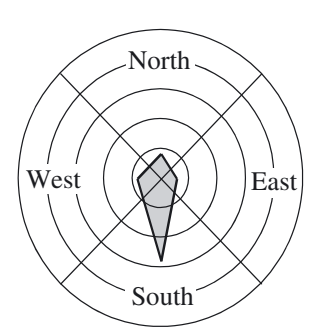

$\mathrm{a}(18) * * *$

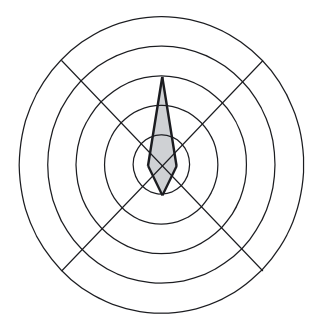

a $(10) * * *$

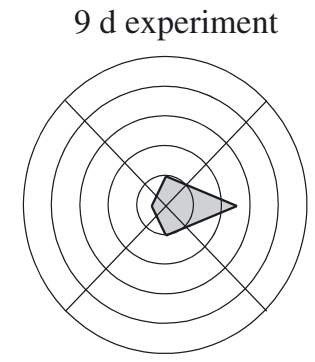

b $(10) * * *$

$40 \mathrm{~d}$ experiment

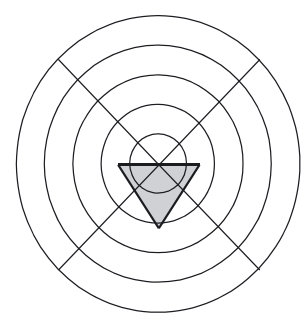

b (7) $* * *$

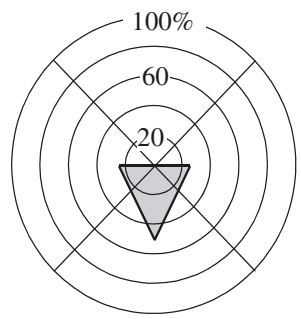

c $(8) * * *$

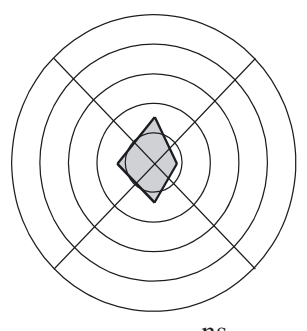

c (19) $)^{\text {ns }}$

Fig. 5. Strongylocentrotus droebachiensis. Modified polar plots indicating mean directional movement of sea urchins out of six $1 \mathrm{~m}^{2}$ plots in 4 orientations (north, south, east, or west; see Fig. 1). The $9 \mathrm{~d}$ experiment represents the urchins collected from the inner ring and the $40 \mathrm{~d}$ experiment includes urchins from both the inner and outer rings. Number of urchins recaptured is in parentheses. ${ }^{* * *} \mathrm{p}<0.001, \mathrm{~ns}=$ not significant $\left(\chi^{2}\right.$-tests $)$

For small and large juveniles, densities in the inner portion of the cleared areas after $48 \mathrm{~h}$ were very low compared to the initial densities in both trials with and without algal food ( $t$-tests, $\mathrm{p}<0.05, \mathrm{n}=3$ ). In contrast, the densities of adults in the trials without food were similar to initial densities $(\mathrm{p}=0.32, \mathrm{n}=3)$. Furthermore, the density of adults in the inner area in the trials with food was 6 times greater than the initial densities $(p<0.001)$. These results indicate slow movement of juveniles and rapid movement of adults,

Table 3. Strongylocentrotus droebachiensis. Results of 2-way (Food, Size) ANOVAs applied to the densities of sea urchins recaptured in experimental plots during the immigration experiment (see Fig. 5). Outer area data were rank-transformed

\begin{tabular}{|lrrrc|}
\hline Source of variation & df & \multicolumn{1}{c}{ MS } & \multicolumn{1}{c|}{$F$} & $\mathrm{p}$ \\
\hline Inner area & & & & \\
Food & 1 & 11755.6 & 289.1 & $<0.001$ \\
Size & 2 & 16094.0 & 385.8 & $<0.001$ \\
Food $\times$ Size & 2 & 10416.2 & 256.1 & $<0.001$ \\
Residual & 12 & 40.7 & & \\
Outer area & & & & \\
Food & 1 & 46.2 & 5.1 & 0.04 \\
Size & 2 & 136.2 & 14.9 & $<0.001$ \\
Food $\times$ Size & 2 & 27.7 & 3.0 & 0.09 \\
Residual & 12 & 9.2 & & \\
\hline
\end{tabular}

a pattern consistent with the observations in the emigration studies. The increases in small and large juveniles were greater in the outer portion of the circular plots, likely because of the proximity $(<16 \mathrm{~cm})$ to the high density of urchins just outside the urchin removal plots. The presence of algal food at the center of the plots had no detectable effect on small and large juveniles, but increased the density of adults, especially in the inner area (Fig. 6).

\section{DISCUSSION}

The present study demonstrates a change in the movement of urchins with increasing size. An ontogenetic shift in behaviour from being relatively sedentary to active foraging occurs abruptly at about $15 \mathrm{~mm}$ in test diameter. The estimated number of large juveniles (10 to $15 \mathrm{~mm}$ diameter) in the release site and inner ring after $9 \mathrm{~d}$ was 50.9\% (39.0\% were in the release site) which compares to $7.8 \%$ for adults (15 to $40 \mathrm{~mm}$ diameter). Only $3.7 \%$ (1/27) tagged adults measuring 15 to $20 \mathrm{~mm}$ diameter were recaptured.

Choosing appropriate temporal and spatial scales was difficult given the paucity of information on urchin movement, particularly for juveniles. In this first study, making use of calcein tagging to examine movement, we could have sampled at a completely inappropriate time scale. For example, the urchins could have moved so much that we would have recaptured few individuals. As it turned out, the scales selected provided considerable information for juveniles, but the spatial scale was too small and the temporal scale too long to adequately quantify the movement of adults ( $>15 \mathrm{~mm}$ diameter). Nevertheless, the rapid disappearance of tagged adults from our 6 plots indicated that their movement was much greater than that of juveniles.

In addition to providing evidence for the limited movement of juveniles compared to the rapid movement of adults, our inward movement trials showed that adult movement, but not juvenile, was strongly influenced by the presence of food. Himmelman \& Nédélec (1990) observed similar size-related differences in field experiments examining the movement of urchins towards bundles of different species of macroalgae that were attached to the bottom. Also, numerous studies report that large urchins rapidly aggregate on new food sources, for example drift algae (Garnick 


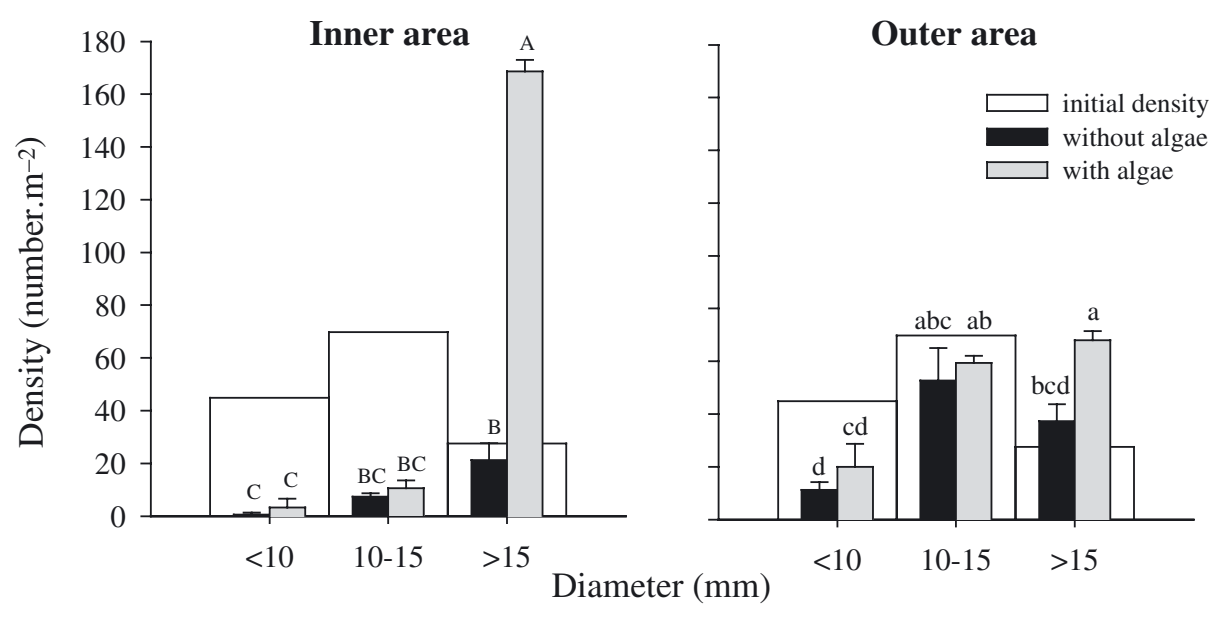

Fig. 6. Strongylocentrotus droebachiensis. Densities of sea urchins in the $48 \mathrm{~h}$ immigration experiment. Half of the clearings had a piece of the alga Alaria esculenta (a preferred food) in the centre. Columns sharing the same letter are not significantly different (SNK test, $\mathrm{p}<0.05$ ). Vertical bars represent standard errors

1978, Bernstein et al. 1983, Vadas et al. 1986, Hagen \& Mann 1994). Vadas (1977) suggested that large urchins adopt a sit-and-wait strategy to reduce their metabolic rate while waiting for drift algae. However, our fluorescent tagging trials on urchin barrens with no fleshy macrophytes indicate that large urchins are not sedentary over a $9 \mathrm{~d}$ timescale.

Active foraging of adults on barrens should be highly advantageous, given the stochastic processes determining when and where food materials appear on the bottom. Urchins should benefit from increased foraging involving either random movements or movements aided by distance chemodetection. The dispersion of juveniles around the released areas was directional, but at different directions in each trial, possibly reflecting local conditions (e.g. food, predators, currents).

Our observations suggest that juveniles move short distances and are limited to feeding on coralline algae and detritus (Raymond \& Scheibling 1987). Because these diets permit only limited growth, the smallest size classes can represent the accumulation of several age cohorts (Himmelman 1986). In contrast, growth is thought to be greater for intermediate-size urchins (Himmelman 1986, Raymond \& Scheibling 1987, Russell et al. 1998). The ontogenetic shift at $15 \mathrm{~mm}$ diameter, from being relatively sedentary to active foraging, should provide increased access to food (increased food abundance and quality) and, in turn, enhance growth. It is probably not a coincidence that Strongylocentrotus droebachiensis first develops gonads between 18 and 25 mm diameter (Vadas 1977, Raymond \& Scheibling 1987, Munk 1992, Meidel \& Scheibling 1998), as at this size urchins have increased access to food resources. The above observations suggest that there is a trade-off between the risk of predation and the need to forage to supply energy for growth (somatic and gonadal).
Sedentary behaviour is a common strategy employed by juvenile organisms to minimize predation risk (Werner \& Gilliam 1984, Lima \& Dill 1989) and this may be the case for sea urchins. Our sampling of juveniles required a careful search, as most juveniles were not visible at the surface. The low rate of movement of juveniles is likely related to their tendency to hide under rocks and in crevices, or cover themselves with debris, an adaptation probably developed to escape potential predators such as crabs and fish (Keats et al. 1985, Scheibling \& Hamm 1991). Predation is believed to play an important role in regulating the density of juveniles (McNaught 1999, Balch \& Scheibling 2000). Predation pressure may limit the movement rate of juveniles, and, if so, the increased movement on open surfaces after reaching $15 \mathrm{~mm}$ diameter may reflect a reduced vulnerability to predators. Interestingly, the laboratory studies of Ojeda \& Dearborn (1991) show that the cunner Tautogolabrus adspersus has a strong preference for $<15 \mathrm{~mm}$ diameter urchins, but larger urchins are not consumed, possibly because the cunner has difficulty in handling them. However, gut analyses of cunners reported in the same study showed the presence of some urchins measuring up to $23 \mathrm{~mm}$ diameter. Furthermore, Scheibling (1996) indicates that urchins measuring 15 to $25 \mathrm{~mm}$ diameter have not reached a refuge in size but are probably still subject to predation. Under conditions of low food availability, intraspecific predation (cannibalism) may also present a risk (Himmelman \& Steele 1971, Raymond \& Scheibling 1987, C. Dumont pers. obs.) and this risk is possibly greatest for juveniles. The size distributions for urchins in our study site showed a drop in frequencies between 10 and $20 \mathrm{~mm}$ diameter, which suggests that predation pressure may be an important factor in determining size distributions. 
However, the decrease in frequencies between 10 and $20 \mathrm{~mm}$ diameter likely represents the effect of predators over several years (Himmelman 1986, Meidel \& Scheibling 1998, Russell et al. 1998). Predation probably had little or no impact over the short duration of our dispersion trials ( 9 or $40 \mathrm{~d}$ ) because the size distributions in the trial sites did not change over the period of the experiment. If predation did contribute to decreased recaptures, this was more likely for small adults (15 to $20 \mathrm{~mm}$ diameter) and much less likely for large adults. The hypothesis that increased movement accounted for the decreased recaptures of calceintagged urchins with increasing size is also strongly supported by the immigration experiments. Immigration, which was clearly due to movement, increased markedly with size, and paralleled the decrease recaptures of tagged urchins in the emigration experiments. For example, the proportion of immigrant urchins relative to their initial densities at the sites prior to being removed was $5.6 \%(\mathrm{SE}=1.2)$ for 10 to $15 \mathrm{~mm}$ diameter urchins, $34.9 \%(\mathrm{SE}=4.2)$ for 15 to $20 \mathrm{~mm}$ diameter urchins and $61.7 \%(\mathrm{SE}=21.7)$ for 20 to $25 \mathrm{~mm}$ diameter urchins in the trials without food and the values were $9.3 \%(0.6), 41.7 \% \quad(\mathrm{SE}=30.0), 117.5 \% \quad(\mathrm{SE}=$ 41.6), respectively, in the trials with food. Finally, although no previous studies documented movement rates for small urchins, high rates of adult (>25 mm) movement (several meters per day) have been documented by Garnick (1978) and Duggan \& Miller (2001).

Knowledge about the mobility of urchins of different sizes is important in understanding distribution and size-structure patterns in subtidal areas. During the last decade, commercial urchin harvesting has led to drastic declines in Strongylocentrotus droebachiensis in a number of regions in North America (Keesing \& Hall 1998), and recovery of these populations will depend on both recruitment and migration. The rates of settlement and survival should be the major determinants of the abundance of juveniles in different habitats, given their limited movement. In contrast, the distribution of adults ( $>15 \mathrm{~mm}$ diameter) could be strongly affected by their movement. Calcein tagging can be a useful technique for studying the movement of juveniles. However, it is an inadequate technique for large urchins which can move so rapidly that the likelihood of recapture is small. A better understanding of the factors influencing movement rates of large urchins requires the development of techniques which permit identifying individuals without the bias created by disturbing the animals.

Acknowledgements. We are grateful to D. Drolet, A. Drouin, M. Thompson and G. Wagner for their extensive help during field and laboratory work. The manuscript was further improved by comments from L. Johnson, A. Davis and 3 anonymous reviewers. This study was funded by NSERC and FCAR grants to J.H.H. and financial support was provided to C.P.D. by Québec-Océan and the Biology Department of Université Laval. M.P.R. received support from the Biology Department at Villanova.

\section{LITERATURE CITED}

Agatsuma Y, Nakata A, Matsuyama K (2000) Seasonal foraging activity of the sea urchin Strongylocentrotus nudus on coralline flats in Oshoro Bay in south-western Hokkaido, Japan. Fish Sci 66:198-203

Balch T, Scheibling RE (2000) Temporal and spatial variability in settlement and recruitment of echinoderms in kelp beds and barrens in Nova Scotia. Mar Ecol Prog Ser 205: 139-154

Bernstein BB, Schroeter S, Mann KH (1983) Sea urchin (Strongylocentrotus droebachiensis) aggregating behaviour investigated by a subtidal multifactorial experiment. Can J Fish Aquat Sci 40:1975-1986

Chapman ARO (1981) Stability of sea urchin dominated barren grounds following destructive grazing of kelp in St. Margaret's bay, eastern Canada. Mar Biol 62:307-311

Conover WJ (1980) Practical nonparametric statistics. John Wiley \& Sons, New York

Dayton PK (1985) Ecology of kelp communities. Ann Rev Ecol Syst 16:215-245

Duggan RE, Miller RJ (2001) External and internal tags for the green sea urchin. J Exp Mar Biol Ecol 258:115-122

Ebert TA (1988) Calibration of natural growth lines in ossicles of 2 sea urchins, Strongylocentrotus purpuratus and Echinometra mathaei, using tetracycline. In: Burke RD, Mladenov P, Lambert P, Parsley RL (eds) Echinoderms: proceedings of the sixth international echinoderm conference. Balkema, Rotterdam, p 435-444

Ebert TA (2001) Growth and survival of post-settlement sea urchins. In: Lawrence JM (ed) Edible sea urchins: biology and ecology. Elsevier, New York, p 79-102

Freeman SM (2003) Size-dependent distribution, abundance and diurnal rhythmicity patterns in the short-spined sea urchin Anthocidaris crassispina. Estuar Coast Shelf Sci 58: 703-713

Garnick E (1978) Behavioral ecology of Strongylocentrotus droebachiensis (Müller) (Echinodermata: Echinoidea). Aggregating behaviour and chemotaxis. Oecologia 37: $77-84$

Hagen NT (1996) Tagging sea urchins: a new technique for individual identification. Aquaculture 139:271-284

Hagen NT, Mann KH (1994) Experimental analysis of factors influencing the aggregating behaviour of the green sea urchin Strongylocentrotus droebachiensis (Müller). J Exp Mar Biol Ecol 176:107-126

Himmelman JH (1986) Population biology of green sea urchins on rocky barrens. Mar Ecol Prog Ser 33:295-306

Himmelman JH, Nédélec H (1990) Urchin foraging and algal survival strategies in intensely grazed communities in eastern Canada. Can J Fish Aquat Sci 47:1011-1026

Himmelman JH, Steele DH (1971) Foods and predators of the green sea urchin Strongylocentrotus droebachiensis in Newfoundland waters. Mar Biol 9:315-322

Hines AH, Wolcott TG, Gonzalez-Gurriaran E, GonzalesEscalante JL, Freire J (1995) Movement patterns and migrations in crabs: telemetry of juvenile and adult behaviour in Callinectes sapidus and Maja squinado. J Mar Biol Assoc UK 75:27-42

Keats DW, South GR, Steele DH (1985) Ecology of juvenile 
green sea urchins (Strongylocentrotus droebachiensis) at an urchin dominated sublittoral site in eastern Newfoundland. In: Keegan BF, O'Connor BDS (eds) Echinodermata. Balkema, Rotterdam, p 295-302

Keesing JK, Hall KC (1998) Review of harvests and status of world sea urchin fisheries points to opportunities for aquaculture. J Shellfish Res 17:1597-1604

Kobayashi S, Taki J (1969) Calcification in sea urchins: I. A tetracycline investigation of growth of the mature test in Strongylocentrotus intermedius. Calcif Tissue Res 4: 210-223

Konar B (2000) Seasonal inhibitory effects of marine plants on sea urchins: structuring communities the algal way. Oecologia 125:208-217

Lawrence JM (1975) On the relationships between marine plants and sea urchins. Oceanogr Mar Biol Annu Rev 13: 213-286

Lima SL, Dill LM (1989) Behavioral decisions made under the risk of predation: a review and prospectus. Can J Zool 68: 619-640

McNaught D (1999) The indirect effects of macroalgae and micropredation on the post-settlement success of the green sea urchin in Maine. PhD thesis, University of Maine, Orono

Meadows PS, Campbell JI (1972) Habitat selection by aquatic invertebrates. Adv Mar Biol 10:271-382

Meidel SK, Scheibling RE (1998) Size and structure of the sea urchin Strongylocentrotus droebachiensis in different habitats. In: Mooi R, Telford M (eds) Echinoderms: San Francisco. Balkema, Rotterdam, p 737-742

Munk JE (1992) Reproduction and growth of green urchins Strongylocentrotus droebachiensis (Müller) near Kodiak, Alaska. J Shellfish Res 11:245-254

Norkko A, Cummings VJ, Thrush SF, Hewitt JE, Hume T (2001) Local dispersal of juvenile bivalves: implications for sandflat ecology. Mar Ecol Prog Ser 212:131-144

Ojeda FP, Dearbon JH (1991) Feeding ecology of benthic mobile predators: experimental analyses of their influence in rocky subtidal communities of the Gulf of Maine. J Exp Mar Biol Ecol 149:13-44

Paine RT, Vadas RL (1969) The effects of grazing by sea urchins, Strongylocentrotus spp., on benthic algal populations. Limnol Oceanogr 14:710-719

Palmer MA, Allan JD, Butman CA (1996) Dispersal as a regional process affecting the local dynamics of marine and stream benthic invertebrates. Trends Ecol Evol 11: 322-326

Propp MV (1977) Ecology of the sea urchin Strongylocentrotus droebachiensis of the Barents Sea: metabolism and regulation of abundance. Soviet J Mar Biol 3:27-37

Raymond BG, Scheibling RE (1987) Recruitment and growth of

Editorial responsibility: John Lawrence (Contributing Editor), Tampa, Florida, USA the sea urchin Strongylocentrotus droebachiensis (Müller) following mass mortalities off Nova Scotia, Canada. J Exp Mar Biol Ecol 108:31-54

Russell MP, Meredith RW (2000) Natural growth lines in echinoid ossicles are not reliable indicators of age: a test using Strongylocentrotus droebachiensis. Invertebr Biol 119: 410-420

Russell MP, Ebert TA, Petraitis PS (1998) Field estimates of growth and mortality of the green sea urchin, Strongylocentrotus droebachiensis. Ophelia 48:137-153

Scheibling RE (1996) The role of predation in regulating sea urchin populations in eastern Canada. Oceanol Acta 19: 421-430

Scheibling RE, Hamm J (1991) Interactions between sea urchins (Strongylocentrotus droebachiensis) and their predators in field and laboratory experiments. Mar Biol 110:105-116

Scheibling RE, Hatcher BG (2001) The ecology of Strongylocentrotus droebachiensis. In: Lawrence JM (ed) Edible sea urchins: biology and ecology. Elsevier, New York, p 271-306

Scheibling RE, Hennigar AW, Balch T (1999) Destructive grazing, epiphytism, and disease: the dynamics of sea urchin-kelp interactions in Nova Scotia. Can J Fish Aquat Sci 56:2300-2314

Underwood AJ (1997) Experiments in ecology: their logical design and interpretation using analysis of variance. Cambridge University Press, Cambridge

Vadas RL (1977) Preferential feeding: an optimization strategy in sea urchins. Ecol Monogr 47:337-371

Vadas RL (1990) Comparative behaviour of tropical and boreal sea urchins. In: Hughes RN (ed) Behavioural mechanisms of food selection. Springer-Verlag, Berlin, p 480-514

Vadas RL, Elner RW, Garwood PE, Babb IG (1986) Experimental evaluation of aggregation behaviour in the sea urchin Strongylocentrotus droebachiensis. Mar Biol 90: 433-448

Vadas RL, Smith BD, Beal B, Dowling T (2002) Sympatric growth morphs and size bimodality in the green sea urchin (Strongylocentrotus droebachiensis). Ecol Monogr 72:113-132

Wahle RA, Steneck RS (1992) Habitat restrictions in early benthic life: experiments on habitat selection and in situ predation with the American lobster. J Exp Mar Biol Ecol 157:91-114

Werner EE, Gilliam JF (1984) The ontogenetic niche and species interactions in size-structured populations. Annu Rev Ecol Syst 15:393-425

Zar JH (1999) Biostatistical analysis. Prentice-Hall, Englewood Cliffs, NJ

Submitted: September 2, 2003; Accepted: May 25, 2004

Proofs received from author(s): July 1, 2004 